\title{
Ovine White-Liver Disease (OWLD). Serum Copper and Effects of Copper and Selenium Supplementation
}

\author{
By Martha J. Ulvund
}

State Veterinary Research Station for Small Ruminants, Sandnes, Norway.

\begin{abstract}
Ulvund, M. J.: Ovine white-liver disease (OWLD). Serum copper and effects of copper and selenium supplementation. Acta vet. scand. 1990, 31, 287-295. - Serum copper was generally higher in lambs affected with ovine white-liver disease (OWLD) than in cobalt/vitamin $B_{12}$ supplemented lambs grazing the same pastures. Although the copper content of the grass was very low on the OWLD pastures, dosing lambs with $\mathrm{Cu}$ alone resulted in worsening of the clinical condition and aggravation of clinical pathology. Dosing with selenium had no effect on OWLD. Dosing with a combination of $\mathrm{Co}$, Se and $\mathrm{Cu}$ resulted in normal lamb growth and normal laboratory tests. Lambs growing well on other pastures $(\mathrm{H})$ showed elevated serum $\mathrm{Cu}$ when they were subclinically $\mathrm{B}_{12}$ deficient.
\end{abstract}

sheep; cobalt/vitamin $B_{12}$ deficiency.

\section{Introduction}

Ovine white-liver disease (OWLD) occurs in vitamin $\mathrm{B}_{12}$ deficient lambs in coastal Norway, and may be prevented by supplementation or dosing with vitamin $\mathrm{B}_{12}$ (Ulvund \& Pestalozzi 1990a). On some pastures lambs grow satisfactorily without developing OWLD, although they some years are $B_{12}$ deficient, a fact indicating that cofactors may be decisive as to whether OWLD will develop or not (Ulvund 1990a). Examination of grass samples revealed that OWLD grass had significantly lower $\mathrm{Cu}$ content than the grass where the lambs had subclinical $\mathbf{B}_{12}$ deficiency (Ulvund \& Pestalozzi 1990b).

There are only few studies on serum $\mathrm{Cu}$ in lambs with OWLD and simple Co deficiency. MacPherson et al. (1976) reported high plasma $\mathrm{Cu}$ in $\mathrm{Co}$ deficient sheep, while Sutherland et al. (1979) observed high or normal serum $\mathrm{Cu}$ in OWLD.

As a concurrent deficiency of both Co and $\mathrm{Cu}$ (coast disease) causes illthrift in Austra- lia (Marston et al. 1938, Lee 1951, Lee 1975) and Sweden (Schwan et al. 1987), efforts were made to clarify the $\mathrm{Co} / \mathrm{Cu}$ interaction in OWLD. Selenium responsive unthriftiness has also been reported in lambs (McLean et al. 1959), and it was important to evaluate the significance of $\mathrm{Se}$ as well.

In this paper serum $\mathrm{Cu}$ concentrations in $\mathrm{Co} / \mathrm{B}_{12}$ deficient lambs with OWLD, in lambs with subclinical $\mathrm{Co} / \mathrm{B}_{12}$ deficiency, and in $C o / B_{12}$ sufficient lambs are reported. The effect of $\mathrm{Cu}$ and Se supplementation on performance and clinical pathology in lambs grazing OWLD pastures is also given.

\section{Materials and methods}

A. Serum copper in OWLD lambs and in lambs supplemented with cobalt/vitamin $B_{12}$ Survey of experimental design has been given (Ulvund \& Pestalozzi 1990a, Ulvund 1990a). Altogether 458 twin lambs of the Dala and Rygja breeds were included in the project (1981-1986). Lambs designed S gra- 
zed OWLD pastures, either moderately or heavily $\mathrm{Co}$ fertilized (SCo, $\mathrm{SCo}$ ) or not $\mathrm{Co}$ fertilized (S), and lambs designed $\mathrm{H}$ grazed control pastures situated $15 \mathrm{~km}$ apart. The $H$ lambs were subclinically $B_{12}$ deficient some years, but they never developed OWLD. Groups of lambs on the OWLD or $\mathrm{H}$ pastures were supplemented with $\mathrm{Co}$ or regularly injected with vitamin $\mathrm{B}_{12}$ as described earlier (Ulvund \& Pestalozzi 1990a). The supplementation is indicated by symbols, as explained in Tables 1 and 2. Number of lambs sampled within each group was generally 4-6 (Ulvund 1990b).

Serum $\mathrm{Cu}$ was determined by atomic absorption spectrophotometry according to manufacturer's manual. During 1981-1983 Unicam SP 90 (Unicam Instruments Ltd., Cambridge) was used, while Pye Unicam SP9-200 (Philips) was used during 1984-1986. Seronorm ${ }^{\circledR}$ (Nyegaard \& Co. $\mathrm{A} / \mathrm{S}$, Oslo) was used as quality control.

\section{B. Copper and selenium supplementation}

Group SCuO: Six lambs were dosed with copper oxide needles (Copporal, 2 g, Beecham Animal Health, England) and put on OWLD pastures on May 15, 1984.

Group SCoSeCu: Six lambs on OWLD pastures were dosed (July 1, 1985) with cobalt/selenium/copper pellets (CoSeCure for lambs, $17 \mathrm{~g}$ pellets with $13.4 \% \mathrm{w} / \mathrm{w}$ copper as $\mathrm{CuO}, 0.3 \% \mathrm{w} / \mathrm{w}$ selenium as $\mathrm{Se}$, and $0.5 \%$ w/w cobalt as $\mathrm{Co}_{3} \mathrm{O}_{4}$, Chance Pilkington Ltd., The Wellcome Foundation Ltd., $\mathrm{UK})$. One of the SCoSeCu lambs had no pellet in the forestomachs at slaughter, and had to be excluded from the group.

Group SSe: Six lambs on OWLD pastures were dosed (July 1, 1985) with selenium pellets (Permasel 5\%, ICI, Tasman Vaccine Laboratory, Bury St. Edmunds, Suffolk, UK).
All lambs were weighed weekly. Concentrations of blood constituents were measured as reported earlier (Ulvund 1990a, b).

\section{Results}

A. Serum copper in OWLD lambs and in lambs supplemented with cobalt/vitamin $B_{12}$ The unsupplemented $S$ group (OWLD) usually had mean serum $\mathrm{Cu}$ above the $\mathrm{Co} / \mathrm{B}_{12}$ supplemented $\mathrm{S}$ groups from the end of July to early/mid September. The lambs which received regular $B_{12}$ injections ( $\mathrm{SB}_{12}$ lambs) most often had the lowest values. Results from 1982-1984 illustrate this pattern (Fig.

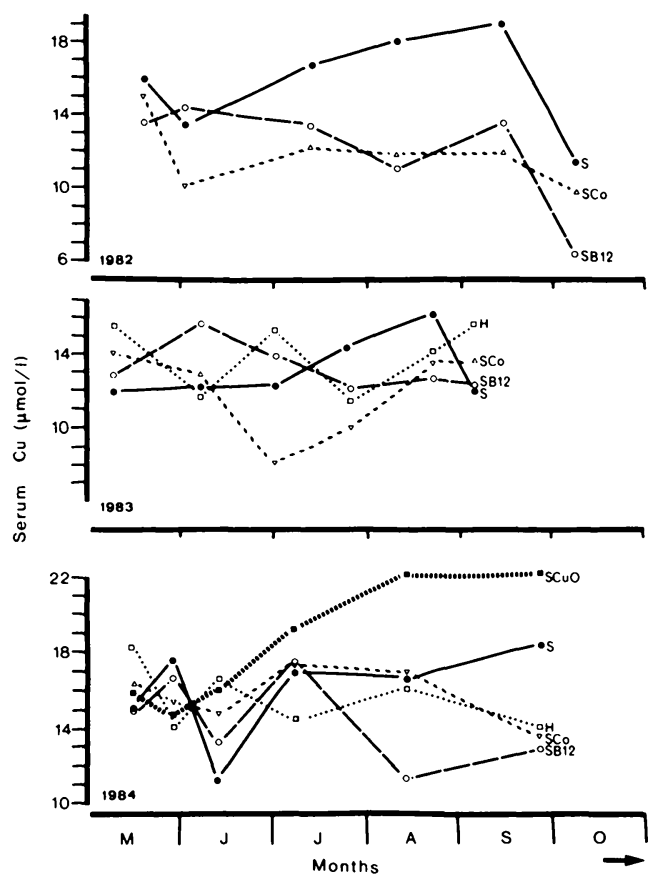

Figure 1. Mean serum $\mathrm{Cu}(\mu \mathrm{mol} / \mathrm{l})$ in various groups of lambs throughout grazing in 1982-1984. For group symbols, see Tables 1-3. In 1982, 6 lambs were sampled $(n=6)$ in the $S$ and $\mathrm{SB}_{12}$ groups, while 4 were sampled in the SCo group. In 1983, $n$ was 4 in all groups, except for $n=16$ in the $S$ group at the first 4 samplings, and $n=13$ at the last two. In 1984, $n=5$ in all groups. 
Table 1. Mean ( $\pm \mathrm{sd})$ serum $\mathrm{Cu}(\mu \mathrm{mol} / \mathrm{l})$, glutamate dehydrogenase (GLDH, U/L), plasma vitamin $B_{12}(\mathrm{pmol} / \mathrm{l})$ and methyl malonic acid (MMA, $\left.\mu \mathrm{mol} / \mathrm{l}\right)$ in experimental lambs, 1985. Four lambs were examined in each group $(n=4)$, except in the $\mathrm{SCoSeCu}$ group where $\mathrm{n}=3$.

\begin{tabular}{|c|c|c|c|c|c|c|}
\hline & & May & June & July & August & October \\
\hline$c u$ & $\begin{array}{l}\mathrm{S} \\
\mathrm{SSe} \\
\mathrm{SCoSeCu} \\
\mathrm{SB}_{12} \\
\mathrm{H}\end{array}$ & $\begin{array}{l}13 \pm 0.7 \\
13 \pm 0.8 \\
15 \pm 1.0 \\
13 \pm 1.7 \\
13 \pm 1.4\end{array}$ & $\begin{array}{r}9 \pm 1.7 \\
9 \pm 0.9 \\
12 \pm 3.0 \\
12 \pm 1.8 \\
11 \pm 1.1\end{array}$ & $\begin{array}{l}12 \pm 2.1 \\
13 \pm 0.8 \\
11 \pm 1.4 \\
13 \pm 1.3 \\
15 \pm 1.8\end{array}$ & $\begin{array}{l}11 \pm 0.2 \\
15 \pm 1.3 \\
10 \pm 0.9 \\
11 \pm 1.8 \\
13 \pm 1.7\end{array}$ & $\begin{array}{r}9 \pm 2.9 \\
12 \pm 4.9 \\
13 \pm 0.7 \\
11 \pm 1.8 \\
18 \pm 1.1\end{array}$ \\
\hline$G L D H$ & $\begin{array}{l}\mathrm{S} \\
\mathrm{SSe} \\
\mathrm{SCoSeCu}\end{array}$ & $\begin{array}{l}3 \pm 2.4 \\
9 \pm 5.7 \\
3 \pm 0.9\end{array}$ & $\begin{array}{r}8 \pm 2.7 \\
16 \pm 6.5 \\
5 \pm 1.5\end{array}$ & $\begin{array}{r}64 \pm 45 \\
42 \pm 16 \\
6 \pm 3.7\end{array}$ & $\begin{array}{r}37 \pm 33 \\
32 \pm 16 \\
7 \pm 3.8 \\
\end{array}$ & $\begin{array}{c}6 \pm 0.6 \\
22 \pm 17 \\
11 \pm 11\end{array}$ \\
\hline$B_{12}$ & $\begin{array}{l}\text { S } \\
\text { SSe } \\
\text { SCoSeCu }\end{array}$ & $\begin{array}{l}386 \pm 141 \\
445 \pm 104 \\
528 \pm 110\end{array}$ & $\begin{array}{r}117 \pm 69 \\
75 \pm 20 \\
92 \pm 30\end{array}$ & $\begin{array}{c}248 \pm 254 \\
83 \pm 22 \\
484 \pm 113\end{array}$ & $\begin{array}{r}90 \pm 20 \\
153 \pm 53 \\
407 \pm 83\end{array}$ & $\begin{array}{l}556 \pm 499 \\
329 \pm 56 \\
656 \pm 171\end{array}$ \\
\hline$M M A$ & $\begin{array}{l}\text { S } \\
\text { SSe } \\
\text { SCoSeCu }\end{array}$ & $\begin{array}{l}0.4 \pm 0.3 \\
0.6 \pm 0.5 \\
1.2 \pm 0.6\end{array}$ & $\begin{array}{l}3.0 \pm 0.5 \\
5.0 \pm 3.0 \\
6.0 \pm 6.7\end{array}$ & $\begin{array}{r}12 \pm 8.4 \\
14 \pm 5.8 \\
1.0 \pm 1.1\end{array}$ & $\begin{array}{c}3.5 \pm 3.5 \\
12 \pm 14 \\
27 \pm 27\end{array}$ & $\begin{array}{l}1.4 \pm 1.2 \\
2.0 \pm 2.3 \\
3.0 \pm 2.9\end{array}$ \\
\hline
\end{tabular}

S : Lambs grazing OWLD pastures.

SCoSeCu: S-lambs dosed on July 1 with $\mathrm{CoSeCu}$ pellets.

SSe : S-lambs dosed on July 1 with Se pellets.

$\mathrm{SB}_{12} \quad$ : S-lambs injected from July 1 and every second week with vitamin $\mathrm{B}_{12}$ (2 mg hydroxocobalamin).

$\mathrm{H} \quad$ : Lambs grazing control pastures situated $15 \mathrm{~km}$ from the OWLD pastures.

1). The SCo groups had significantly lower values than the $\mathrm{S}$ groups $(\mathrm{p}<0.05)$ in August 1982 and 1983 and September 1984. In 1985 , mean serum $\mathrm{Cu}$ in the $\mathrm{S}$ lambs was low throughout July-October (Table 1), but the range in individual values was wide (4.7-15 $\mu \mathrm{mol} / \mathrm{l})$. Values for the $H$ lambs were most often in between those of the $S$ and $\mathrm{SB}_{12}$ lambs, except in 1985 and 1986, when serum $\mathrm{Cu}$ was highest in the $\mathrm{H}$ lambs during late summer (Tables 1-2).

Co fertilization (SCo, SCo+) or admittance to Co lick (SColick) had a lowering effect on serum $\mathrm{Cu}$ during all years (Fig. 1, Table 2).
A similar effect of Co was also seen in $\mathrm{H}$ lambs (HCo, HColick, Table 2).

\section{B. Effect of copper and selenium supplementation}

The effect of dosing with $\mathrm{Cu}$ or Se alone, or together with $\mathrm{Co}$, on live weight (lw) is shown in Fig. 2. Dosing with $\mathrm{Cu}$ alone $(\mathrm{SCuO})$ resulted in further weight decrease. When $\mathrm{Cu}$ was dosed together with $\mathrm{Se}$ an $\mathrm{Co}$ ( $\mathrm{SCoSeCu}$ ), performance was good. Dosing with $\mathrm{Se}(\mathrm{SSe})$ did not improve weight gain significantly.

Clinically, the $6 \mathrm{SCuO}$ lambs were more 
Table 2. Mean ( $\pm \mathrm{sd})$ serum $\mathrm{Cu}(\mu \mathrm{mol} / \mathrm{l})$ in various groups of lambs, 1986.

Six lambs were examined in each group.

\begin{tabular}{lrrrrc}
\hline & May & \multicolumn{1}{c}{ June } & \multicolumn{1}{c}{ August } & September & October \\
\hline S & $12 \pm 1.9$ & $10 \pm 3.5$ & $14 \pm 4.0$ & $12 \pm 3.5$ & - \\
SCo & $12 \pm 1.6$ & $8 \pm 2.5$ & $8 \pm 8.5$ & $6 \pm 2.8$ & - \\
SCO+ & $13 \pm 4.2$ & $11 \pm 3.0$ & $10 \pm 3.9$ & $9 \pm 4.8$ & - \\
SColick & $11 \pm 1.6$ & $10 \pm 3.3$ & $10 \pm 2.2$ & $8 \pm 3.6$ & - \\
\hline H & $14 \pm 3.1$ & $13 \pm 0.7$ & $15 \pm 2.2$ & $19 \pm 2.6$ & $17 \pm 4.7$ \\
HColick & $12 \pm 2.0$ & $11 \pm 2.3$ & $13 \pm 1.7$ & $14 \pm 3.4$ & $12 \pm 3.5$ \\
HCo & $12 \pm 5.7$ & $12 \pm 1.0$ & $15 \pm 1.6$ & $15 \pm 2.8$ & $13 \pm 1.7$ \\
\hline
\end{tabular}

S : Lambs grazing OWLD pastures.

SCo : Lambs grazing OWLD pastures fertilized with $\mathrm{Co}\left(\mathrm{CoSO}_{4}, 1 \mathrm{~kg} / \mathrm{ha}\right)$ in $1980,1981 \& 1982$.

SCO+ : Lambs grazing OWLD pastures fertilized with Co $(1 \mathrm{~kg} / \mathrm{ha})$ in 1980, 1981, 1982, 1985\& 1986.

SColick : Lambs grazing OWLD pastures having access to Co enriched salt lick.

$\mathrm{H} \quad$ : Lambs grazing control pastures.

HCo : Lambs grazing control pastures fertilized with Co $(2 \mathrm{~kg} / \mathrm{ha})$ in 1986.

HColick : Lambs grazing control pastures having access to Co enriched salt lick.

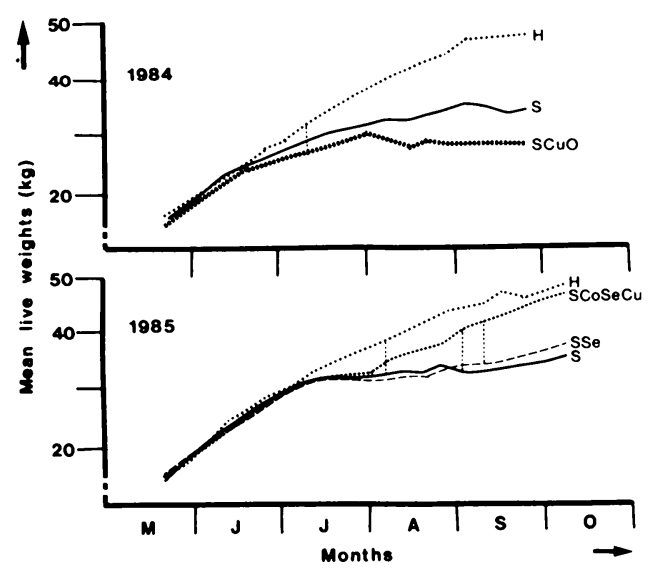

Figure 2. Mean weekly live weights $(\mathrm{kg})$ in groups of lambs throughout grazing. The initial point of significant difference $(p<0.05)$ between groups are indicated by broken vertical lines. For explanation of group symbols, see Tables 1-3. Number of lambs within each group (n) was 24 within the $\mathrm{H}$ group, and 6 within the other groups, except the $\mathrm{SCoSeCu}$ group where $\mathrm{n}=5$. severely affected than the untreated S lambs. All were thin and weak throughout AugustSeptember, with eye discharge, and 2 were icteric. The $\mathrm{SCoSeCu}$ lambs appeared normal. The SSe lambs did not differ from the untreated S lambs (Ulvund \& Pestalozzi 1990a).

Dosing with $\mathrm{CuO}$ significantly elevated serum $\mathrm{Cu}$ in August-September when all individual values were above $19 \mu \mathrm{mol} / \mathrm{l}$ (Fig. 1). Dosing with CoSeCure kept mean serum $\mathrm{Cu}$ on a level like that of $B_{12}$ treated lambs (Table 1). CuO dosing otherwise resulted in similar clinical pathology as that seen in the S lambs (Ulvund 1990a), but changes were more pronounced. During the later part of grazing, mean packed cell volume (PCV) was reduced to $25 \%$, as compared to $32 \%$ for the untreated $\mathrm{S}$ lambs, mean plasma glucose was below $3.3 \mathrm{mmol} / \mathrm{l}$, serum iron (SI) above $43 \mu \mathrm{mol} / 1$ and total cholesterol was 
Table 3. Mean ( \pm sd) serum glutamate dehydrogenase (GLDH, U/L), plasma vitamin $B_{12}(\mathrm{pmol} / \mathrm{l})$ and methyl malonic acid (MMA, $\left.\mu \mathrm{mol} / \mathrm{l}\right)$ in 5 lambs dosed at pasture outlet (may 15, 1984) with copper oxide needles (SCuO).

\begin{tabular}{lcccccc}
\hline & \multicolumn{5}{c}{ Dates of blood sampling } \\
\cline { 2 - 7 } & May 15 & May 28 & June 12 & July 9 & Aug. 13 & Sept. 25 \\
\hline GLDH & $6 \pm 7$ & $41 \pm 29$ & $47 \pm 32$ & $43 \pm 29$ & $102 \pm 92$ & $48 \pm 53$ \\
B 12 & $301 \pm 147$ & $301 \pm 147$ & $81 \pm 16$ & $47 \pm 10$ & $411 \pm 153$ & $98 \pm 22$ \\
MMA & $1.0 \pm 0.6$ & $6.0 \pm 2.4$ & $21 \pm 7.6$ & $74 \pm 45$ & $188 \pm 102$ & $116 \pm 62$ \\
\hline
\end{tabular}

below $1 \mathrm{mmol} / \mathrm{l}$. Serum urea was similar to amounts in the $\mathrm{S}$ lambs. Mean serum glutamate dehydrogenase (GLDH) was elevated, plasma vitamin $\mathrm{B}_{12}$ lowered and methylmalonic acid (MMA) elevated already from June (Table 3).

In CoSeCure supplemented lambs, PCV, glucose and SI were similar to values in the $\mathrm{Co} / \mathrm{B}_{12}$ supplemented ones. Serum GLDH was low (Table 1). All had sufficient $B_{12}$ status during July-October, but 2 lambs had elevated plasma MMA in August (Table 1). The Se dosed lambs showed haematological values similar to those of the untreated $S$ lambs (Table 1).

\section{Discussion}

\section{A. Serum copper in OWLD lambs and Co/B 12 supplemented lambs}

Normal blood $\mathrm{Cu}$ in sheep may vary according to breed and haemoglobin (Hb) type (Wiener et al. 1974), and alterations are also associated with the onset and course of several diseases (Corrigall et al. 1976). In this examination, breed and $\mathrm{Hb}$ type were evenly distributed within the groups, and the lambs and various controls were subject to regular clinical examination as well as examination at slaughter or autopsy.

Our lambs with OWLD most often had elevated serum $\mathrm{Cu}$ in the earlier phase of the disease, i. e. during July-August, as compared with the $\mathrm{Co} / \mathrm{B}_{12}$ supplemented lambs.
Variation in serum $\mathrm{Cu}$ was greater during the later phase (September-October), when amounts might be lowered. One lamb which died early of OWLD in July 1981, had a serum $\mathrm{Cu}$ concentration of $49 \mu \mathrm{mol} / \mathrm{l}$. In 1985 , when serum $\mathrm{Cu}$ in the $\mathrm{S}$ lamb was low during July-August, growth was better than during other years, and plasma vitamin $B_{12}$ was higher, and MMA lower as well (Ulvund \& Pestalozzi 1990a, Ulvund 1990a). Sutherland et al. (1979) also found that mean plasma $\mathrm{Cu}$ was higher in lambs with acute OWLD, while it was lower in the chronic form.

The elevated serum $\mathrm{Cu}$ seen in $\mathrm{H}$ lambs some years, and also the lowering effects of Co supplementation, correlate well with a concomitant subclinical and simple $\mathrm{B}_{12}$ deficiency recorded in these lambs (Ulvund 1990b). There are very few earlier reports on this. In Co deficient sheep, MacPherson et al. (1976) found that mean serum $\mathrm{Cu}$ was about $16 \mu \mathrm{mol} / \mathrm{l}$, while it was below 14 $\mu \mathrm{mol} / \mathrm{l}$ when the sheep were Co sufficient. Six steers fed a diet low in both $\mathrm{Co}$ and $\mathrm{Cu}$ developed Co deficiency in 6 to 10 months, but failed to develop $\mathrm{Cu}$ deficiency (MacPherson et al. 1973). Mean plasma $\mathrm{Cu}$ increased from 11 to $13 \mu \mathrm{mol} / \mathrm{l}$ during the first 3 months of that experiment, but decreased thereafter.

Our results may indicate that OWLD lambs either have increased intestinal absorption 
or increased release of $\mathrm{Cu}$ from the liver to the blood as compared with $\mathrm{Co} / \mathrm{B}_{12}$ sufficient lambs. As erythrocyte $\mathrm{Cu}$ was not examined, a decreased ability of erythrocytes to take up $\mathrm{Cu}$ cannot be excluded. The results indicate that $B_{12}$ deficiency, and OWLD, may conceal a marginal/deficient $\mathrm{Cu}$ condition. The lower serum $\mathrm{Cu}$ seen in some OWLD lambs during late summer may indicate depletion of the liver stores.

\section{B. Copper and selenium supplementation}

Studies of coast disease in Australia showed that supplementation with $\mathrm{Cu}$, as well as with Co, was necessary for successful treatment (Marston et al. 1938). Hannam et al. (1980), however, who conducted their experiments on Co deficiency in lambs on a property near the site where Marston et al. made their investigations of coast disease, obtained no significant effect of $\mathrm{Cu}$ on live weight (lw) gain.

A growth response to $\mathrm{Cu}$ has been found in experimental $\mathrm{Cu}$ deficiency in lambs ( $\mathrm{Ho}$ well 1968), and studies from Scotland in lambs grazing hill pastures improved by liming and reseeding have also shown that growth can be improved by $\mathrm{Cu}$ supplementation (Whitelaw et al. 1977, 1979, Suttle et al. 1984, Suttle 1986). When CuO needles (2 g) were given as a single dose to 3-5 weeks old lambs, they were $3.3 \mathrm{~kg}$ heavier than the undosed at weaning (Whitelaw et al. 1983).

Mitchell et al. (1982) obtained no effect of $\mathrm{Cu}$ treatment on $\mathrm{lw}$ gain in lambs with OWLD. The fact that $\mathrm{Cu}$ dosing worsened the OWLD condition in our case and caused icterus in 2 lambs, may in fact indicate that OWLD lambs are more sensitive to $\mathrm{Cu}$ intakes. The elevation of serum $\mathrm{Cu}$ after dosing with $\mathrm{CuO}$ needles was larger than that seen after similar dosing of 5 weeks old lambs in Scotland (Whitelaw et al. 1980). In the 2 icteric lambs, serum $\mathrm{Cu}$ was higher during June-September (overall mean 23 $\mu \mathrm{mol} / \mathrm{l})$ than in the other $3 \mathrm{SCuO}$ lambs (overall mean $18 \mu \mathrm{mol} / \mathrm{l}$ ), as were GLDH and MMA amounts. Elevated serum GLDH indicating hepatic damage was in fact detected 2 weeks before rise of serum $\mathrm{Cu}$ above $19 \mu \mathrm{mol} / \mathrm{l}$. Haemoglobinemia was not seen in these lambs, but plasma was yellow in August-September. The 3 others within the group had red plasma in September. Sheep on marginal Co intakes are more susceptible to Se poisoning than sheep on adequate Co (Gardiner 1966a), but similar mechanisms have not earlier been reported for $\mathrm{Cu}$.

Intakes of plants containing alkaloids ( $\mathrm{He}$ liotropium europaeum) may cause liver damage in such a way that the liver retains $\mathrm{Cu}$, increasing the susceptibility to $\mathrm{Cu}$ poisoning (Seaman 1987). In connection with liver damage due to lupinosis, increased serum $\mathrm{Cu}$ has been found (Gardiner 1966b). Although the lupins were deficient in $\mathrm{Cu}$, higher morbidity and mortality rates were found when the lambs were supplemented with $\mathrm{Cu}$. Mean serum $\mathrm{Cu}$ was not higher in the $\mathrm{Cu}$ supplemented sheep than in the sheep not exposed to $\mathrm{Cu}$, but liver $\mathrm{Cu}$ was significantly higher.

The lamb which had no $\mathrm{CoSeCu}$ pellet in the forestomacs at slaughter, is worth mentioning in this respect. This lamb had very high liver $\mathrm{Cu}(307 \mathrm{mg} / \mathrm{kg}$ wet weight), indicating that the pellet had been dissolved and absorbed. It showed reduced growth from mid July on, and in October it was 11 $\mathrm{kg}$ lighter than the others within the $\mathrm{SCoSeCu}$ group. Serum $\mathrm{Cu}$ was between 8.8 $\mu \mathrm{mol} / \mathrm{l}$ and $18 \mu \mathrm{mol} / \mathrm{l}$ during June-October, while serum GLDH was elevated from mid July on (41-80 U/L). Plasma $B_{12}$ was low ( $<150 \mathrm{pmol} / \mathrm{l})$ throughout June-August, and plasma MMA increased from $1 \mu \mathrm{mol} / \mathrm{l}$ in June to 6 in October, all values indicating 
liver damage, $\mathrm{B}_{12}$ deficiency, and $\mathrm{Cu}$ toxicity. Dissolution and absorption of glass boluses have not been reported by others.

Lambs which develop OWLD show signs of liver damage at an earlier stage of disease (Ulvund 1990a). The damage may perhaps render the liver more vulnerable to $\mathrm{Cu}$, resulting in $\mathrm{Cu}$ accumulation in the liver when $\mathrm{Cu}$ is dosed.

Live weight (lw) increases up to several $\mathrm{kg}$ have been found in lambs dosed with selenium as compared with undosed (Robertson \& During 1961, Blaxter 1963). Growth response to a combined Co and Se deficiency has also been obtained (McLean et al. 1959, Hartley et al. 1959, Andrews et al. 1964), and $\mathrm{a} \mathrm{Se}$ and $\mathrm{Cu}$ interaction has been reported (Hill et al. 1969). In lambs with OWLD, however, Mitchell et al. (1982) found no effect of Se dosing. The lack of growth response to $\mathrm{Se}$ in our lambs therefore correlates with their findings.

The results from our investigation showed that dosing with soluble glass pellets containing $\mathrm{Co}$, Se and $\mathrm{Cu}$ prevented OWLD. Lw increase started 4-5 weeks after dosing, and the growth rate was similar to that obtained by Co supplementation or $B_{12}$ treatment, and signs of liver damage were not observed. The glass pellet was developed for use in sheep by Telfer et al. (1983) and Knott et al. (1985), and Care et al. (1985) showed that the $17 \mathrm{~g}$ pellet provided sufficient Co, $\mathrm{Se}$ and $\mathrm{Cu}$ to lambs from application at 5-6 weeks of age until slaughter at 5 months of age. In lambs at risk to Co and Se deficiency, Ellis et al. (1987) obtained a significant lw response, similar to the response obtained by $\mathrm{B}_{12}$ dosing. Driver et al. (1986) found the pellets effective in treatment of $\mathrm{Cu}$ deficient lambs.

In our case, serum $\mathrm{Cu}$ was not particularly elevated in the $\mathrm{SCoSeCu}$ lambs, as compared with the untreated or Se treated lambs. This is in accordance with the findings of Allen et al. (1984) in lambs on summer pasture. The effect of CoSeCure dosing on plasma $B_{12}$ appeared 3 weeks after dosing, and values were significantly elevated for at least 2 months. According to Ellis et al. (1987), dosing with CoSeCure maintained sufficient plasma $B_{12}$ for more than 4 months in lambs at risk to Co and Se deficiency, while Millar et al. (1988) found a significant effect on serum $\mathrm{B}_{12} 12$ months after dosing lambs on Se deficient, $\mathrm{Co} / \mathrm{Cu}$ adequate pastures.

In conclusion, OWLD lambs had higher serum $\mathrm{Cu}$ than $\mathrm{Co} / \mathrm{B}_{12}$ supplemented lambs on the same pastures, and although OWLD grass was low in $\mathrm{Cu}$ contents, dosing with $\mathrm{Cu}$ worsened the clinical disease and aggravated clinical pathology.

\section{References}

Allen WM, Sansom BF, Gleed PT, Mallinsom $C B$, Drake $C F$ : Boluses of controlled release glass for supplementing ruminants with copper. Vet. Rec. 1984, 115, 55-57.

Andrews ED, Grant AB, Stephenson BJ: Weight responses of sheep to cobalt and selenium in relation to vitamin $B_{12}$ and selenium concentrations in liver and kidney. N. Z. J. agric. Res. 1964, 7, 17-27.

Blaxter $K L$ : The effect of selenium administration on the growth and health of sheep on Scottish farms. Brit. J. Nutr. 1963, 17, 105115.

Care AD, Anderson PJB, Illingworth $D V$, Zervas $G, T e l f e r S B$ : The effect of soluble-glass on the copper, cobalt and selenium status of Suffolk Cross lambs. In: Mills CF, Bremner I, Chesters JK (eds.): Trace elements in Man and Animals. TEMA-5. Proc. 5th int. Symp. on trace elements in man and animals, Aberdeen 1984, CAB, London 1985, p. 717-719.

Corrigall $W$, Dalgarno AC, Ewen LA, Williams $R B$ : Modulation of plasma copper and zinc concentrations by disease states in ruminants. Vet. Rec. 1976, 99, 396-397. 
Driver PM, Eames C, Telfer SB: Efficacy of soluble glass boluses containing copper, cobalt and selenium in store lambs. In: Proc. 6th int. Conf. on production disease in farm animals, Belfast 1986, 108-111.

Ellis NJS, Shallow M, Judson GJ: Weight gains of lambs treated with a soluble glass bullet containing cobalt, selenium and copper. Aust. vet. J. 1987, 64, 93-94.

Gardiner $M R$ : Chronic selenium toxicity studies in sheep. Aust. vet. J. 1966a, 42, 442-448.

Gardiner MR: Mineral metabolism in sheep lupinosis. J. comp. Path. 1966b, 76, 107-120.

Hannam RJ, Judson GJ, Reuter DJ, McLaren $L D, M c F a r l a n e ~ J D$ : Effect of vitamin $\mathrm{B}_{12}$ injections on the growth of young merino sheep. Aust. J. agric. Res. 1980, 31, 347-355.

Hartley WJ, Drake C, Grant $A B$ : Selenium and animal health. N. Z. J. agric. 1959, 99, 259264.

Hill MK, Walker SD, Taylor AG: Effects of marginal deficiences of copper and selenium on growth and productivity of sheep. N. Z. J. agric. Res. 1969, 12, 261-270.

Howell $J M c C$ : The effect of experimental copper deficiency on growth, reproduction and haemopoiesis in the sheep. Vet. Rec. 1968, 83, 226-227.

Knott $P$, Algar B, Zervas $G$, Telfer SB: Glass a medium for providing animals with supplementary trace elements. In: Mills CF, Bremner I, Chesters JK (eds.): Trace elements in man and animals. TEMA-5. Proc. 5th int. Symp. on trace elements in man and animals, Aberdeen 1984. CAB, London 1985, p. 708714.

Lee HJ: Cobalt and copper deficiencies affecting sheep in South Australia. J. Dep. Agric. S. Aust. 1951, 54, 475-532.

Lee HJ: Trace elements in animal production. In: Nicholas DJD, Egan AR (eds.): Trace elements in soil-plant-animal systems. Academic Press, London 1975, p. 39-54.

MacPherson A, Moon FE, Voss RC: Some effects of feeding young steers on a diet deficient in both cobalt and copper. Brit. vet. J. 1973, 129, 414-426.
MacPherson A, Moon FE, Voss RC: Biochemical aspects of cobalt deficiency in sheep with special reference to vitamin status and a possible involvement in the eatiology of cerebral necrosis. Brit. vet. J. 1976, 132, 294-308.

Marston HR. Thomas RG, Murnane D, Lines EWL, McDonald IW, Moore HO, Bull LB. Studies on coast disease of sheep in South Australia. Commonwealth Scientific and Industrial Res. Org., Melbourne 1938 (Bull. no. 113).

McLean JW, Thompson CG, Claxton JH: Growth responses to selenium in lambs. N. Z. vet. J. 1959, 7, 47-52.

Millar KR, Meads Wj, Albyt AT, Scahill BG, Sheppard $A D$ : The retention and efficacy of soluble glass boluses for providing selenium, cobalt and copper to sheep. N. Z. vet. J. 1988, 36, 11-14.

Mitchell PJ, McOrist S, Thomas KW, McCausland IP: White liver disease of sheep. Aust. vet. J. 1982, 58, 181-184.

Robertson TG, During C: Live weight responses to selenium in lambs, but few responses to cobalt. N. Z. J. Agric. 1961, 103, 306-310.

Schwan O, Jacobsson SO, Frank A, Rudby-Martin L, Petersson LR: Cobalt and copper deficiency in Swedish landrace pelt sheep. Application of diagnosis in flock-related deficiency diseases. J. vet. Med. A, 1987, 34, 709-718.

Seaman JT: Pyrrolizidine alkaloid poisoning of sheep in New South Wales. Aust. vet. J. 1987, 64, 164-167.

Sutherland RJ, Cordes DO, Carthew GC: Ovine white liver disease - an hepatic dysfunction associated with $B_{12}$ deficiency. $N$. Z. vet. J. 1979, 27, 227-232.

Suttle $N F$, Jones DG, Woolliams JA, Woolliams $C$, Wiener G: Growth responses to copper and selenium in lambs of different breeds on improved hill pastures. Proc. Nutr. Soc. 1984, 43, $103 \mathrm{~A}$.

Suttle NF: Copper deficiency in ruminants; recent developments. Vet. Rec. 1986, 119, 519522.

Telfer SB, Zervas G, Carlos G: Curing or preventing deficiencies in copper, cobalt and se- 
lenium in cattle and sheep using tracerglass. Canad. J. anim. Sci. 1984, 64, 243-235.

Ulvund MJ: Ovine white-liwer disease (OWLD). Vitamin $B_{12}$ and methylmalonic acid (MMA) estimations in blood. Acta vet. scand. 1990a, 31, 267-275.

Ulvund MJ: Ovine white-liver disease (OWLD). Changes in blood chemistry. Acta vet. scand. 1990b, 31, 277-286.

Ulvund MJ, Pestalozzi M: Ovine white-liver disease (OWLD) in Norway: Clinical symptoms and preventive measures. Acta vet. scand. 1990a, 31, 53-62.

Ulvund MJ, Pestalozzi M: Ovine white-liver disease (OWLD). Botanical and chemical composition of pasture grass. Acta vet. scand. 1990b, 31, 257-265.

Whitelaw A, Armstrong RH, Evans CC, Fawcett $A R$ : An investigation into copper deficiency in young lambs on an improved hill pasture. Vet. Rec. 1977, 101, 229-230.

Whitelaw A, Armstrong RH, Evans CC, Fawcett $A R$ : A study of the effects of copper deficiency in Scottish blackface lambs on improved hill pasture. Vet. Rec. 1979, 104, 455-460.

Whitelaw A, Armstrong RH, Evans CC, Fawcett $A R$, Russell AJF: Effects of oral administration of copper oxide needles to hypocupraemic sheep. Vet. Rec. 1980, 107, 87-88.
Whitelaw A, Russell AJF, Armstrong RH, Evans $C C$, Fawcett $A R$, MacDonald AJ: Use of cupric oxide needles in the prophylaxis of induced copper deficiency in lambs grazing improved hill pastures. Vet. Rec. 1983, 112, 382-384.

Wiener G, Hall JG, Hayter S, Field AC, Suttle $N F$ : Relationships between haemoglobin type and copper concentrations in whole blood and its components in sheep of different breeds. Anim. Prod. 1974, 19, 291-299.

\section{Sammendrag}

Kvitleversjuke (kobolt/vitamin $B_{12}$ mangel) hos lam. Serum kopper og effekt av dosering med kopper og selen.

Serum kopper var som regel høyere hos lam med kvitleversjuke (OWLD) enn hos dem som fikk tilskudd av kobolt eller vitamin $\mathbf{B}_{12}$. Til tross for att graset på sjukdomsbeitene var kopperfattig ble sjukdomstilstanden forverret når lam på disse beitene ble dosert med kopper, og forandringene i blodbildet ble forsterket. Dosering med selen hadde ingen virkning på sjukdommen. Dosering med en kombinasjon av kobolt, selen og kopper resulterte $i$ normal tilvekst, og normale forhold $i$ blodbildet. Kontrollama viste stigning i serum kopper når de var subklinisk $\mathrm{Co} / \mathrm{B}_{12}$ deficitte.

(Received January 27, 1989; accepted October 9, 1989).

Reprints may be requested from: Martha J. Ulvund, State Veterinary Research Station for Small Ruminants, Høyland, P. O. Box 264, N-4301 Sandnes, Norway. 